\title{
APRENDIZAGEM DA ATENÇÃO E OS MODOS DE SUBJETIVAÇÃO PEDAGÓGICA E INFORMACIONAL
}

\author{
Maria Helena Nardin \\ Regina Orgler Sordi \\ Universidade Federal do Rio Grande do Sul, Porto Alegre, Brasil
}

RESUMO: O presente artigo tem como objetivos precípuos: apresentar e discutir as formas de atenção e suas relações com a aprendizagem na contemporaneidade, buscando fazer aproximações com duas formas de construção subjetivas: a pedagógica e a informacional. Pretende-se apresentar, em seguimento, os resultados de um estudo piloto realizado em uma primeira série do ensino fundamental. $O$ objetivo da pesquisa foi estudar os modos de atenção dispensados por alunos e professores durante o processo de ensino e aprendizagem e analisar seus desdobramentos. O estudo sugeriu que a sala de aula pode ser um espaço de aprendizagem de um modo de atenção aberto à invenção, a medida que se torna possível experimentar, principalmente, o acolhimento do inesperado, que surge num momento de ruptura do foco atencional, e a instalação de uma dinâmica de atuação comunicativo-dialógica-interacional, que implica na valorização do pensamento e do princípio de co-operação.

PALAVRAS-CHAVE: Aprendizagem processual; subjetividade pedagógica e informacional; atenção recognitiva e inventiva.

\section{THE LEARNING OF ATTENTION AND PEDAGOGIC AND INFORMATIONAL SUBJECTIVITIES}

ABSTRACT: The main goal of this paper is to discuss the ways attention has been understood and its relations with learning in the contemporary world, by trying to relate it with two ways of subjective constructions: the pedagogic and the informational. Following is the presentation of the results of a pilot study done with the first grade of a grammar school. The purpose of the research was to study the ways attention was experienced between students and teachers during the learning process and analyze its development. It suggested that the classroom could be a space of learning of an attention open to invention as long as it is possible to experience the sudden reception that emerges from a rupture of the focus. Also, it suggested the need of a dialogical dynamics of communication based on the principle of interaction and co-operation.

KEYWORDS: Processual learning; pedagogic and informational subjectivity; recognitive and inventive attention.

O problema que se deseja apresentar diz respeito à relação entre atenção e aprendizagem. No contexto atual, a atenção tem se revelado uma "condição para" que o sujeito possa adaptar-se às exigências do mundo. Porém, estudos vindos, principalmente, da Psicologia e da vertente fenomenlógica das Ciências Cognitivas têm mostrado que ela pode ser compreendida como "efeito" de uma aprendizagem. Sendo assim, o modo como é entendida implica diretamente na compreensão do seu estatuto, sendo possível, então, reconceituá-la e pensar numa ampliação do seu funcionamento e dos mecanismos que a ligam à aprendizagem.

Crary (1999) mostra, em seus estudos mais recentes, que, para entender o sujeito atento atual, é preciso compreender as transformações pelas quais têm passado os modos de existir da sociedade ocidental, que está su- bordinada à lógica do capital. Desde o final do século XIX, esta lógica tem produzido discursos, saberes, tecnologias e práticas sociais que entretecem uma rede de relações, que se articulam e produzem mutações nas formas de perceber, conhecer e prestar atenção. A partir desse novo cenário, cuja ênfase tem recaído no individualismo e na competitividade, criam-se outros dispositivos de constituição do sujeito, que nos levam a pensar na saturação, na velocidade e no excesso, características marcantes da era da informação, obrigando-nos a determinados modos de atuar que exigem pontualidade, focalização e reconhecimento. Para isto, precisamos desenvolver uma capacidade de focalização em pontos múltiplos e responder com avidez de novidade. A atenção, então, passa a ser condição para a realização de tarefas e para o processamento de informações. 
Há consenso entre vários autores (Corea \& Lewkowiz, 2005; Crary, 1999; Kastrup, 2004) de que os modos como ouvimos, olhamos ou nos concentramos em qualquer coisa têm um caráter profundamente histórico. Sendo assim, nossa maneira de estarmos atentos não é ditada pela biologia ou por algum fenômeno imediato, mas é mediada por nossas experiências de vivências num determinado contexto histórico-cultural.

O que se verifica, então, é um paradoxo no que diz respeito ao conceito de atenção subjacente àquela requerida para a aprendizagem e a que é objeto de estudo no campo dos déficits atencionais. A categoria conhecida como Transtorno de Déficit de Atenção implica uma noção de atenção como função cerebral mensurável responsável pela capacidade do sujeito de manter a seletividade e a constância da atenção.

A partir da hipótese de que a atenção possui qualidades que não são homogêneas, propõe-se transladar o pensamento de uma atenção requerida em sala de aula e caracterizada pelo "ato de prestar atenção" para um conceito de atenção que, segundo Crary (1999), nos remete a duas inflexões. Por um lado, ressoando com um sentido de "tensão", de "ser esticado, estendido" e, por outro, de "esperar". Isto implica a possibilidade de uma "fixação, de segurar algo em contemplação", em cuja experiência o sujeito atento está "tanto imóvel, quanto sem fundação". Trata-se de um movimento continuado, que emerge das diferentes experiências vividas pelo sujeito e de um movimento de detenção/fixação, condição necessária para uma produção de sentido. Ou seja, há um continuum atenção-desatenção, quando a "desatenção", caracterizada por uma suspensão no tempo, permite ao sujeito um momento de ruptura com o aqui e o agora sem perda da força de relação com o foco inicial.

Com o enfoque na heterogeneidade e volatilidade da atenção, foram-se produzindo interrogantes que conduziram a uma pesquisa, cujo propósito foi observar as relações ensino-aprendizagem em sala de aula de primeira série do ensino fundamental e estudar aquelas que pudessem se revelar propícias para a aprendizagem de um modo de atenção de caráter mais inventivo, capaz de novas aberturas. A partir do encontro com algumas práticas pedagógicas tratou-se de compreender, dentre outras coisas, como se organizam as experiências que potencialmente poderiam produzir um modo de atenção possibilitador de uma "cognição inventiva" (Kastrup, 1999).

Pretende-se, aqui, tecer considerações que apontam para algumas características desse espaço, enfatizando aquilo que nomeamos de "dinâmica de conversações comunicativo-dialógica-interacional".

\section{Modos de atender, modos de ensinar, modos de subjetivar}

Assim como nossas crenças, convicções e estilos de vida, também nossas instituições estão mudando antes que possam se solidificar. Tudo, neste momento, está constantemente sendo desmontado, sem a perspectiva de uma permanência. Inserida nesse panorama de transformações institucionais, a escola parece continuar sua prática de medir resultados, domar o processo de aprender concebido como transmissão de informações-conhecimentos, manter sua característica de ser marcada por pontos de partida e pontos de chegada, respondendo a uma certa ordem e a uma certa disciplina com vistas a atingir determinados resultados.

Imersos num mundo cujas novas tecnologias da informação são parte de um conjunto de forças movido pela lógica da produção e pela lógica da velocidade somos convocados constantemente a outros modos de sentir, olhar, agir, pensar, prestar atenção. Alguns autores como Corea e Lewkowicz (2005), Crary (1999), Ibáñez (1996) estão em acordo diante da afirmativa de que vivemos na era da informação, onde se produz uma "subjetividade midiática ou informacional" (Corea \& Lewkowicz).

Entendendo a comunicação como dispositivo de produção de subjetividade, Corea e Lewkowicz (2005) analisam as transformações que se operaram no processo de passagem de um período em que a comunicação se caracterizava por ser "codificada" -constituída por um conjunto de regras e de significações compartilhadas e por um sistema de proibições e restrições - para um período em que se torna uma "comunicação informacional". Parece importante tentar compreender a transformação produzida por este movimento no processo de subjetivação para, desde aí, poder pensar sobre a existência de uma possível diferença de atuação da atenção em atividades específicas da aprendizagem escolar e outras atividades cotidianas.

A escola tem sido, desde um longo período, uma instituição pensada e fundada para formar os "homens de amanhã", supondo a existência de uma temporalidade pensada em etapas, dando sentido ao fazer educativo. Experimentando um modo de relação transferencial estabelecido entre as diferentes instituições por onde os indivíduos transitavam, a escola moderna, tanto quanto a família, o exército, a fábrica e até mesmo os hospitais e as prisões, asseguravam as operações disciplinares necessárias para a produção do cidadão do futuro (Foucault, 1975/2001). A escola era, portanto, suporte da subjetividade oficial; e uma instauração de uma codificação garantia-lhe a função paradigmática de uma instituição disciplinar. O cidadão que ela formava era um indivíduo definido por sua relação com uma lei fundada no princípio revolucionário de igualdade: todos tinham os mes- 
mos direitos e deveres, ou seja, as proibições e permissões valiam igualmente para todos, independentemente de seu lugar na sociedade. Este processo ia resultando na produção de uma "subjetividade estatal" (Corea \& Lewkowicz, 2005). Como efeito dessa subjetividade, a comunicação, baseada nas operações do código lingüístico compartilhado, tornava-se possível pela via da narrativa histórica divulgada na escola, por práticas, discursos e manifestações patrióticas escolares e extraescolares diversas, que garantiam a inserção do sujeito na história portando um passado estável e sendo conduzido a um futuro previsível.

Na medida em que a modernidade foi criando um campo para o desenvolvimento da industrialização e das tecnologias da informação, o lugar do Estado vem sendo ocupado lentamente pelo capital e conduzindo a um esgotamento que vem resultando no esgotamento daquela subjetividade sólida. Desta forma, as instituições disciplinares vêm perdendo o solo de sustentação que as apóiam, bem como sua força constituinte: o código lingüístico comum entre as instituições. Deflagra-se, assim, a desintegração e o enfraquecimento dos discursos até então vigentes, produzindo o enfraquecimento das instituições responsáveis pela constituição das identidades, o que tem resultado num rearranjo nas formas de subjetivação. $\mathrm{O}$ modo de produção capitalista e tudo o que o caracteriza, tal como, liberdade de mercado, liberdade de ir e vir, esvaziamento das instâncias responsáveis pela garantia dos direitos (como o Estado), aceleração do ciclo de inovação e melhoramento dos produtos, gestão da descentralização da produção, flexibilidade nos papéis profissionais, entre outros, vêm sendo apontados como responsáveis por novos modos de ser e de sentir.

Os modos de disciplinar também têm passado a viver uma crise: os meios de confinamento, as fábricas, as escolas e as famílias vêm sofrendo uma transformação, na medida em que novas forças, que não são estatais, anunciam-se.

O marketing é uma dessas novas forças de controle social, que, conforme assinala Deleuze (1972/1992), caracteriza-se, não mais pela necessidade do confinamento, mas pelo controle contínuo e ilimitado e por comunicação instantânea. Se durante a modernidade as estratégias de controle consistiam no esquadrinhamento do tempo, do espaço e dos movimentos, resultando na constituição de "corpos dóceis" (Foucault, 1975/2001), na contemporaneidade, a dominação se dá através do capital financeiro. As instituições tornam-se impotentes, pois seu propósito deixa de ser o comum, de forjar o cidadão. Os governos competentes, então, tratam de pensar nas reformulações que supostamente são necessárias. Fala-se em reformar a escola, a indústria, os hospitais, a prisão e até mesmo o exército e as famílias, pois já são consideradas impotentes em sua tarefa de produzir regras, sentidos e lugares de enunciação. A rigidez de outrora, a sistematicidade e a fixidez foram se convertendo em fluidez (do capital) e rapidez (da informação). A experiência de espaço e tempo também sofreu uma transformação radical: a lógica do espaço não é mais a lógica dos lugares, mas dos fluxos; a lógica do tempo não é uma lógica da continuidade, mas da pontualidade do instante. Há cada vez mais fluxos de informação em tempo real. Podemos ir a todos os lugares sem sair, efetivamente, do lugar. Assim, a palavra instantaneidade significa ao mesmo tempo realização imediata, exaustão e desaparecimento do interesse. A provisoriedade, nestes novos tempos, se torna regra; a gestão do presente, uma obrigatoriedade, e o movimento contínuo, uma exigência. A ênfase, então, fica colocada na adaptação.

Todos estes movimentos vão culminando com a destituição do lugar do cidadão que, aos poucos, vai sendo ocupado pelo indivíduo. O indivíduo deve ser considerado "uma realidade fabricada por essa tecnologia específica de poder que se chama a disciplina" (Foucault, 1975/2001, p. 161). Segundo Foucault, os processos de individualização são a principal característica das sociedades de controle, porque já não se trata mais de proibir mas, ao contrário, de prescrever o comportamento que cada indivíduo deve ter. No espaço escolar, a lista de prescrições busca a uniformidade: desde a ordenação dos conteúdos, do desempenho e dos alunos por idade e por série, até a exigência de que todos devem ser atentos, calmos e saber escutar. Aprender a fazer fila, ir ao banheiro e beber água durante o recreio é tão fundamental quanto escrever nas linhas do caderno, saber atender ordens, copiar do quadro e ser caprichoso.

Segundo Corea e Lewkowicz (2005, p. 43), as alterações mais recentes que se produziram afetam, fundamentalmente, a comunicação. Na era da informação, diz a autora, "a comunicação deixou de existir. Não importa se é comunicação verbal, midiática ou midiatizada. O que se esgotou é o paradigma mediante o qual pensamos, durante quase um século, os fenômenos da significação e da produção de subjetividade".

Se antes, para a autora, havia uma subjetividade solidamente instituída, agora, esta subjetividade vem se caracterizando por uma certa instabilidade e precariedade na medida em que as operações e os mecanismos que a constituem deixam de produzir memória, consciência ${ }^{1}$, e saber como outrora, para produzir atualidade, imagem e opinião. Para Corea e Lewkowicz (2005, p. 72), "opinião é uma palavra que não toca subjetivamente a ninguém, que não gera efeitos de coesão", por isto, uma enunciação desta ordem tende a produzir dispersão e impossibilita a relação de comunicação entre os interlocutores. Na sociedade informacional, a informação elimina e anula a relação espaço-temporal da comuni- 
cação. Não há mais interlocução, há, sim, a troca de informações que se limita a uma enunciação.

Para uma comunicação de sentido, segundo Corea e Lewkowicz (2005, p. 44), é preciso que se estabeleçam relações mediadas por um código compartilhado. "A mediação destas relações significa que em uma comunidade de falantes todos os indivíduos remetem os mesmos signos aos mesmo referentes".

Esta ação vinha assegurando e estabilizando o sentido que se tornava comum, através do qual se criava um sentimento de pertencimento. Para que isto se tornasse possível, faziam-se necessárias duas condições: permanência e repetição. Ambas perfeitamente ilustráveis pelo processo de aprendizagem da leitura e da escrita.

$\mathrm{O}$ esquema de comunicação que atravessou várias gerações escolares permitia um vínculo cidadão-estado, aluno-escola, que criava um sentimento de pertencimento. Através desse vínculo, que se constituía no campo da relação escola-nação, a mensagem era compreendida ao ser remetida a um código comum. Ao se esgotarem os referenciais coletivos que serviam de bússola a todos os "cidadãos", o código passou a ser uma entidade inexistente.

Na sociedade informacional, a informação elimina e anula a relação espaço-temporal da comunicação. Não há mais interlocução, há sim a troca de informações. Isto não implica a superioridade de um modo de existência em detrimento do outro, tampouco que devemos nos lamentar pela perda do antigo. Implica sim, pensar que o modo de comunicação antes existente precisa, nestes novos tempos, ser repensado e produzido - não da mesma forma, é claro - já que não é mais uma prática cotidiana. Implica também poder pensar que necessitamos revisar os conceitos de atenção que têm servido de lente para observar o comportamento infantil nas escolas, e que têm sido utilizados para diagnosticar transtornos de déficit de atenção a partir de postulados de uma etiologia biológica.

Não só os referenciais que outrora fundamentavam o fazer pedagógico, nem só os esquemas de comunicação estão sendo desconstruídos, mas também o conceito de aprender tem sido questionado. Paralelamente a todas essas transformações, algumas concepções de aprendizagem foram se constituindo. Uma delas parte do pressuposto que o sujeito aprende a partir da transmissão/apreensão de informações-conhecimentos. A partir desta lógica, a comunicação passa a assumir o estatuto de informação. A ela está ligada uma concepção de que a linguagem tem o papel de representar as coisas do mundo. No campo escolar, tal crença se atualiza na concepção de que a aprendizagem se dá pela recognição, ou seja, pelo reconhecimento de caminhos pré-determinados a serem repetidos. Ao professor cabe emitir uma mensagem que chega ao aluno e é por ele aprendida tal qual foi emitida, atribuindo ao resultado um caráter de maior significação, caracterizando-se como um movimento homogêneo para todos os alunos, cujo percurso vai de um ponto a outro. O que foge a essas orientações é considerado dispersão. Nesta perspectiva, se o aluno não aprende é porque não consegue ficar quieto, não presta atenção e, se não compreende, é porque falta-lhe "maturidade". Tais estigmas são confirmados, muitas vezes, por diferentes diagnósticos: problemas de aprendizagem, TDA/H, problemas emocionais. A partir destes rótulos, diversos são os destinos desses alunos, situando-se entre a reprovação, a promoção por "compaixão" e a evasão.

Com a comunicação assumindo um caráter informacional, não resta aos alunos outra coisa a não ser decodificar, pois a aprendizagem fica esvaziada de sentido. Em virtude desse esvaziamento, perde-se também o interesse pelo outro e por participar da aprendizagem na interlocução com o outro. Todos ficam situados em lugares bem distintos: emissor da mensagem, de um lado; receptor, de outro; professor transmitindo seu conhecimento numa ordem crescente e verticalizada, de um lado; alunos recebendo, de outro.

Do ponto de vista da aprendizagem, a comunicação informacional a reduz ao reconhecimento, à reprodução de experiências já feitas, à repetição do que já foi descoberto, enquanto sua característica de processualidade não pode ser mantida, pois o objetivo é a chegada a um ponto, que se constitui de conceitos fechados e universalizantes. Fica, então, descartada a dúvida, o conflito, a pergunta, a desconstrução conceitual, bem como, a possibilidade de problematização que, conforme aqui compreendida, não equivale a fazer perguntas ou tirar dúvidas, mas a uma "invenção de problemas" (Kastrup, 1999).

A outra concepção de aprendizagem segue o suposto da processualidade. Nesta perspectiva, a linguagem é tomada com sua dimensão de sentido e, citando Deleuze (1976/ 2003, p. 21), "nunca se sabe como uma pessoa aprende; mas, de qualquer forma que aprenda, é sempre por intermédio de signos, perdendo tempo, e não pela assimilação de conteúdos objetivos". A partir desse ponto de vista, o outro tem um lugar significativo, na medida em que se estabelece com ele a possibilidade de uma construção coletiva, sustentada pela aceitação e pela responsabilidade mútua. "Nunca se aprende fazendo como alguém, mas fazendo com alguém”, escreve Deleuze (1976/2003, p. 21). Sendo assim, o aprender passa a ser um movimento que produz questionamentos, um movimento imprevisível, de irrupção de sentido que foge. Já não basta uma comunicaçãoinformacional, é preciso uma atuação que possibilite espaços para práticas criativas, de respeito a todo pensamento e de reconhecimento da própria autoria.

Uma atuação preponderantemente informacional revela uma concepção de que o ato de aprender se dá pela via da transmissão-recepção e vai sustentando a constituição de uma "subjetividade midiática", enquanto que a 
constituição de uma "subjetividade pedagógica" requer uma experiência intra e intersubjetiva.

Diferentemente da "subjetividade midiática", uma "subjetividade pedagógica" caracteriza-se, principalmente, pela capacidade do sujeito de operar sobre o saber, ou seja, estabelecer relações de coesão entre conhecimentos distintos; pela compreensão do sentido das consignas dadas; pela competência na lecto-escrita, que permite uma produção escrita coerente e argumentativa; e por uma certa adequação à situação escolar com a respectiva compreensão e respeito às suas características específicas. Trata-se de uma situação de aprendizagem para a qual é necessária a construção de um espaço subjetivo que possibilite tal ação. A "subjetividade pedagógica" pressupõe um modo de atuar perpassado por uma série de enunciados, de práticas e de rituais e, porque não dizer, um modo de atender que não pode ser da ordem da dispersão.

Após estudos e experiências psicopedagógicas em espaço clínico, já se pode afirmar que o modo como um sujeito aprende e, conseqüentemente, seu modo de estudar e de estar atento na escola se constitui a partir de uma série de fatores, sendo que o modo de ensinar dos ensinantes - a família e o meio sócio-educativo- assume um papel fundamental. Diante de uma concepção de aprendizagem recognitiva, com a informação assumindo um papel central, teremos um modo de atuação daquele que ensina e, conseqüentemente, também um correlativo modo de aprender -transmissão-recepção - que poderia sugerir um modo de atender. Quando um trabalho é mecânico, via de regra, solicita-se uma atenção focalizada. Não obstante, o modo de ensinar daquele que adota uma postura sustentada pela concepção processual, produziria um modo de aprender, possivelmente de caráter mais inventivo, exigindo, por conseguinte, um outro modo de atender.

Em suma, tomando os dos tipos de subjetividade aos quais Corea e Lewkowicz (2005) se referem - a que se produz desde uma "experiência midiática", e outra que se produz desde uma "experiência pedagógica"- pode-se encontrar relação de sentido entre eles e os modos de atenção do sujeito. No primeiro, frente a um sensório absurdamente saturado por uma avalanche de dados, fica identificada a produção de uma atenção dispersa, aberta à simultaneidade. A dispersão (podemos incluir aqui o esquecimento, frequientemente apontado como uma preocupação contemporânea) apresenta-se, neste caso, como um efeito de hiperestimulação sensória, não havendo o envolvimento do sujeito na experiência, pois a velocidade dos estímulos obtura a possibilidade de um encontro consigo, conspirando contra a possibilidade de produção de sentido e de experiência de invenção. A segunda, por sua vez, pode ser pensada enquanto possibilidade de interlocução, para o que se requisita outra forma de atenção: uma atenção ao mesmo tempo concentrada e aberta para um encontro intrasubjetivo.
A partir destas considerações, torna-se compreensível a visibilidade de crianças com baixa capacidade de concentração e com condutas que mostram uma grande movimentação corporal, tendo em vista suas vivências no entorno midiático que multiplicam as vias de conexão com a fluidez da informação. Ao se depararem com um modo de ensinar que não as atende, mas apenas lhes informa, as crianças encontram-se num espaço que reproduz, em um grau diferenciado, os modos de experimentar o mundo. Neste caso, fala-se da exigência de uma atenção focada, típica do "prestar atenção" que, na escola, junto com o "ficar quieto" transforma-se no principal dever dos alunos. Ao referir-se a expressão "prestar atenção", Fernández (2001, p. 214) interroga-nos e nos convoca a pensar sobre o uso do termo no meio escolar.

O que é que 'se paga' quando 'se presta' atenção? Quem paga e por que deveria pagar alguma coisa? O aluno está em dívida quando o professor pede 'pay (paguem) attention, please'? Quando o professor não fala inglês, mas português, pede 'prestem atenção', que vem de prestar/render contas a outro'... Quem paga, o que paga e a quem paga?

A convocação para que os alunos "prestem atenção", normalmente, vem acompanhada de um "olhem para cá". Olhar, então é sinal de atenção, e esse olhar tem endereçamento certo: para a professora e para o quadronegro. A pergunta "Qual o espaço de invenção que ainda resta para alunos e para professores?" fica reverberando.

De outro lado, ao entendermos as práticas pedagógicas como uma "experiência escolar dialógica", seremos conduzidos a levantar a hipótese de que estas práticas exigem doses de atenção distintas daquela que a maioria das crianças e adolescentes experimentam hoje. Tais práticas são capazes de produzir concentração, viabilizando o encontro consigo e uma experiência de invenção. Teremos, não mais a dispersão, mas uma atenção consciente.

O termo "experiência escolar dialógica" faz referência a práticas de interlocução onde duas pessoas se abeiram da mesma realidade com o intuito de se acercarem o mais possível de um sentido compartilhado. $\mathrm{O}$ diálogo sempre envolve um dos interlocutores tanto quanto o outro. Cada interlocutor fala com o outro, e não para ele. Num diálogo estão implicadas ações como concordar, responder, perguntar, discordar, prestar atenção, respeitar o outro em sua diferença.

O que se nos apresentam, então, são experiências distintas: uma, requer rapidez na captura da informação; outra pede tempo de experimentação, duração, permanência; para uma, o objeto é a informação; para outra, é a aprendizagem; uma atua desde a fragmentação e a saturação; outra atua desde a observação, escuta, recebimento, significação e atribuição de sentido à mensagem; uma experimenta apenas o instante; outra segue o curso de um tempo constituído por presente, passado e futuro; 
uma produz tédio porque vive de estímulo em estímulo, sem chance de significar; outra produz invenção, criação, novidade; uma exige que se atenda simultaneamente a várias situações; outra requer concentração.

As questões que se colocam a partir de agora são: Como, então, será possível aprender um modo de atenção inventiva? Será a escola um campo de possibilidades? Que experiências ela deve proporcionar aos alunos cuja subjetividade se constituiu a partir das experiências cotidianas de hiperestimulação?

\section{Delineando os modos de atenção e as interações escolares}

Se uma subjetividade se constitui a partir do modo de experimentar a si e ao mundo, então podemos entendêla como uma construção feita a partir de um conjunto de operações. Que operações podem ser feitas no espaço escolar para que a capacidade atentiva dos alunos se transforme em algo diferente do modo como recebem uma informação? Em outras palavras: que qualidade de experiência escolar produz um modo de atender capaz de novas invenções?

Dois semestres de observações detalhadas em duas turmas de primeira série do ensino fundamental - cuja escolha não obedeceu ao critério ensino público/privado, mas levou em consideração, de um lado, o interesse da direção sobre o tema e, de outro, um conhecimento prévio da atuação pedagógica da professora - permitiram refletir sobre diferentes formas de atender, em sala de aula, e seus efeitos no processo de aprendizagem. O caminho metodológico adotado tem raízes nas pesquisas de caráter qualitativo, com uma abordagem etnográfica que permitiu estudar aspectos da ordem social desse microcosmos. Para esta pesquisa interessavam, especificamente, as relações escolares e os significados que emergem através das falas e ações coletivas. Para facilitar a tarefa de observações, foram utilizadas notas de campo, áudio-gravações, registros e entrevistas abertas. Foram feitas várias leituras dos registros disponíveis e passou-se a analisá-los cuidadosamente para "ver o que estava se passando" na sala de aula. A análise do material sugeriu a indicação de um sinalizador - o breakdown para o estudo de momentos de ruptura da atenção. A utilização do termo breakdown inspira-se em Varela (2003) e, neste estudo, define-se como "efeitos que se expressam na ação dos sujeitos frente a momentos de ruptura do foco atencional". Os dois subtipos foram assim caracterizados: (a) breakdown que resulta em momentos de problematização e (b) breakdown que resulta em momentos divergentes à problematização.

O primeiro, caracteriza-se por colapsos que articulam diversas situações sócio-cognitivas experienciadas pelos sujeitos, em sala de aula, e que são responsáveis pelo "lado autônomo e criativo da cognição" (Varela, 2003); são considerados os momentos de atenção inventiva. Já o segundo, mostra-se na forma de colapsos que, ao emergirem das diversas situações sócio-cognitivas experienciadas pelos sujeitos, não são acolhidos e promovem um retorno ao foco atencional, obstaculizando a cognição inventiva.

Conforme a proposta deste artigo, vamos apenas delinear algumas características do espaço escolar que possibilitou uma experiência de problematização. Tendo em vista a freqüência de práticas de aprendizagem com exclusividade recognitiva e a diversidade de estudos que as abordam, elas não serão referidas neste momento. Todavia, é importante e necessário assinalar que nos protocolos selecionados por revelarem "breakdowns que resultaram em momentos divergentes à problematização", viuse que, quando a professora intervinha sem cessar exigindo "respostas certas" às suas perguntas - característica de um modo de comunicação informacional -, os breakdowns, quando se mostravam, não eram acolhidos, revelando que a focalização no reconhecimento do objeto da aprendizagem empobrecia o processo. Nestes casos, era freqüiente o surgimento da pergunta: "Não estavas prestando atenção?", insinuando uma falta de atenção da criança, quando a falta de atenção parecia ser da professora em relação ao acontecimento - surgimento do inesperado - e ao reconhecimento dos alunos como sujeitos pensantes e afetáveis. Havia um aprisionamento da professora no seu próprio ponto de vista, o que denotava uma fixação de sua atenção em um ponto particular que resultava na negligência de outros e impossibilitava a escuta daquilo que se revelava depois do breakdown. Ao fechar a escuta, a professora fechava-se, também, para a possibilidade de pensar sobre o pensamento das crianças, para o encontro da sua subjetividade com a subjetividade do aluno, para o encontro com a autoria; ela desatendia aos alunos. Seu modo de atender focalizado, voluntário e seletivo mostrou-se um sério obstáculo às descobertas.

Existe a possibilidade de estabelecer uma relação entre o modo de atender dessa professora e seu modo de ensinar. Ficou evidente, para o observador, uma atuação marcada por uma compreensão e por uma postura diante do processo ensino-aprendizagem: cabe à professora o papel de transmissora da mensagem e ao aluno o de receptor. É papel do receptor, num primeiro momento, "gravar" o que ouviu e viu e, noutro, "reproduzir o que gravou”. Numa aprendizagem de tal ordem está envolvida uma atenção voluntária e focalizada, produzindo espaço para a constituição de um modo de subjetivação informacional. A falta de abertura para o inesperado, nesta dinâmica, acaba resultando na constatação de problemas na aprendizagem que, na maioria das vezes, está referida à falta de atenção. 
Retomando nosso objetivo de apresentar uma cena escolar que caracterizasse um momento de acolhimento do breakdown, o protocolo a seguir foi selecionado. A professora apresentou às crianças um desenho de um muro construído com tijolos, sobre o qual se podia ver dez mãos, e fez a seguinte proposta: "Vamos imaginar que tem umas crianças escondidas atrás desse muro. Olhem as mãozinhas delas aqui. Eu quero saber quantas crianças estão escondidas. Mas, olhem só, isto não é suficiente. Eu quero saber como vocês pensaram pra descobrir isto".

Depois de certificar-se de que as crianças haviam chegado a um consenso, a professora propôs que cada grupo revelasse como fizera tal descoberta. Foi nisso que ela se concentrou, e a análise das transcrições das falas nos permitiu observar que naquele espaço de diálogo se passou algo que parece ter sido uma experiência que força a pensar: marca da problematização.

Ao ouvir a afirmação dos colegas de que havia cinco crianças atrás do muro e o relato de que sua descoberta fora feita contando as mãos de dois em dois, o aluno L. comentou: "Uma pessoa pode tá se segurando só com uma mão"... Estava lançado um problema...

A problematização não fora apenas um mero movimento do menino. Algo no desenho (objeto) o forçou a problematizar. Num primeiro momento, L. deixou-se afetar pelo desenho e pelo que ele pôde representar. Olhou-o, escutou os colegas, mas não compartilhou suas idéias. Permaneceu sozinho, durante um bom tempo, observando sua folha para, só depois, integrar-se ao grupo. No momento seguinte, quando da apresentação de um grupo, L. olhou atentamente para os colegas e para a folha que estava sendo apresentada à distância. Possivelmente seu pensamento estava sendo forçado a procurar o sentido do que se mostrava entre o desenho e a fala dos colegas. Ao fazer essa procura, L. inventou um novo problema.

Embora houvesse vários indícios apontando para o fato de que se poderia reconhecer cinco pessoas representadas no desenho, L. afastou-se desse esquema recognitivo. Parece que não foi a presença de um objeto desconhecido, tampouco a identidade do objeto que o forçou a pensar, mas um sentido que escapou ao reconhecimento e que só se viabilizou porque o menino não manteve o foco de sua atenção no familiar (cinco pessoas). Ele suspendeu o processo recognitivo e, ao fazê-lo, definiu uma nova direção para sua atenção que se encontrou com algo novo, de ordem pré-reflexiva. Ao verbalizar seu encontro, L. deu à professora chance de torná-lo objeto de reflexão de todos. Ao deixar-se tocar pela novidade proposta por seu aluno, a professora criou um espaço para compartilhar a experiência de aprendizagem. Ela acolheu a fala de L. e possibilitou que todos pudessem seguir pensando junto com o menino, acionando, não só a possibilidade criadora das crianças, como a sua própria. Ela, en- tão, improvisou um muro-cartolina e criou uma cena que dramatizou com seus atores mirins. Na dramatização, todas as hipóteses foram testadas atrás do muro-cartolina, no qual as crianças iam posicionando-se duas a duas. Inicialmente, a proposta de L. fora rejeitada pela maioria, mas a professora insistiu em fazer pensar sobre o pensado. Algumas crianças argumentaram que não se poderia aceitála porque na encenação havia diferenças de tamanho, de cor e de posicionamento das mãos - o que não se verificava no desenho -, mostrando seu apego no reconhecimento das características físicas do objeto.

É importante assinalar o que se passou antes do breakdown. A consigna "eu quero saber como vocês pensaram" criou um espaço para muitas possibilidades, onde a aprendizagem é o resultado da experiência de cada um na relação com o conhecimento, consigo mesma e com os outros. Não se tratava apenas de "descobrir" o que estava representado ("isso não é o suficiente"), mas de saber, antes de tudo, o que cada um pensou. Percebeu-se que a professora interveio a partir de uma proposta de experiência de autoria de pensamento. A solução do problema era parte importante do processo, mas não a principal.

O espaço que se criou na tentativa de possibilitar o encontro de uns com os outros, onde cada um tivesse a possibilidade de mostrar-se pensando, permitiu acolher o inesperado e, ainda, humorizar, ou seja, brincar com o que aconteceu, acionando a capacidade criadora de todos.

Pelo encontro com estas especificidades na análise desse protocolo, delineou-se, então, o que foi denominado "dinâmica de conversações comunicativo-dialógica". Neste modo de atuar, a atenção é compartilhada e a comunicação adquire sentido a partir da coordenação de pontos de vista, devendo possibilitar situações para a invenção. A instalação de uma dinâmica comunicativodialógica-interacional implica na valorização do pensamento, uma postura corporal que sugere acolhimento e pertencimento, aceitação do outro como legítimo na relação e a vivência de experiências regidas pelo princípio da co-operação e da reciprocidade.

Observou-se, a partir do registro das comunicações, que nenhuma proposição foi rejeitada pela professora, todas elas foram validadas e todos seguiram pensando juntos. Houve uma integração dialógica que só é possível pela via do respeito ao ponto de vista do outro, de forma que o conhecimento é construído a partir da diversidade, sem o objetivo de homogeneizar. Parecia muito difícil para as crianças pensarem outra possibilidade que não aquela cuja resposta ela encontraram e confirmaram. A professora, aberta ao breakdown, dálhe passagem, pois podia manter sua atenção concentrada e aberta, o que viabilizou a experiência de troca vivida por todo o grupo. 


\section{Considerações finais}

As experiências de práticas pedagógicas sustentadas por uma concepção de aprendizagem processual, que, fundamentalmente, deve estar apoiada na comunicação dialógica (Sordi, 1999), têm grandes chances de construir uma capacidade de atenção distinta daquela necessária para $o$ ato de receber informação e da qual boa parte dos alunos carece. A capacidade atentiva, tanto quanto a capacidade de brincar se aprendem; porém ninguém pode ensiná-las. Isto reveste a função de quem ensina de uma importância singular, já que não existem conteúdos, tampouco métodos que possibilitem estas aprendizagens. Elas somente são possíveis na relação com um outro que acredita na capacidade pensante do sujeito, seja criança, jovem ou adulto. Uma relação de tal ordem não pode ficar engessada num modo de comunicaçãoinformacional, pois a uma fixação na informação corresponde uma capacidade de produzir o mesmo, de reproduzir e, para isto, é demandada uma atenção focalizada que descarta a capacidade de problematizar, de inventar; conseqüentemente, ela não supõe um outro pensante na relação. Uma relação da ordem da dialogicidade está aberta para a aceitação do outro como legítimo na relação e, portanto, compartilha a diversidade. Numa cena escolar cotidiana na qual o diálogo está presente, é possível construir um caminho para tratar do sentido como invenção do processo de aprender, em que cognição se mistura à experiência dos cuidados de si.

Se desde uma perspectiva de práticas pedagógicas apoiadas apenas na transmissão de informação pode-se pensar na constituição de um determinado modo de atender; de outro lado, práticas constitutivas de uma subjetividade pedagógicas como, por exemplo, uma "experiência escolar dialógica interacional" pode-se afirmar que tais práticas exigem doses de atenção distintas daquela que a maioria das crianças e adolescentes experimenta hoje. Para que seja possível um enfrentamento com os contextos e práticas da vida diária, é necessário o cultivo das duas possibilidades de atenção - a recognitiva e a inventiva ${ }^{2}$-, mas somente a última é capaz potencializar a aprendizagem.

Numa sala de aula onde se revela a capacidade de mediar a aprendizagem de um modo de atenção aberto à invenção pode-se experimentar o acolhimento do breakdown, uma comunicação dialógia interacional, momentos estéticos e de produção de sentido para o que se diz e faz, práticas coletivas de pensar sobre o pensamento e um trabalho permanente de construção-reconstrução. Tais experiências, ao se tornarem freqüentes na sala de aula, podem possibilitar o exercício de uma certa hegemonia da consciência sobre os apelos sensórios. Teríamos, neste caso, não mais a dispersão que é carac- terística do modo de atender midiático - pois exige do sujeito uma mudança constante do foco -, mas uma atenção consciente, marcada pelo continuum esperar-esticar, fixar-romper, atender-desatender.

\section{Notas}

1. O termo consciência está sendo usado para fazer referência a um sentimento de relação que une a pessoa que experiencia e o objeto experienciado.

2. Para um aprofundamento dos conceitos, sugere-se a leitura de Kastrup (1999).

\section{Referências}

Corea, C., \& Lewkowicz, I. (2005). Pedagogía del aburrido. Escuelas destituidas, familias perplejas. Buenos Aires, Argentina: Paidós.

Crary, J. (1999). Suspensions of perception: Attention, spectacle, and modern culture. Cambridge, MA: MIT Press.

Deleuze, G. (1992). Conversações. São Paulo, SP: Editora 34. (Original publicado em 1972)

Deleuze, G. (2003). Proust e os signos (2. ed.). Rio de Janeiro, RJ: Forense Universitária. (Original publicado em 1976)

Fernández, A. (2001). Os idiomas do aprendente. Porto Alegre, RS: Artmed.

Foucault, M. (2001). Vigiar e punir (24. ed.). Petrópolis, RJ: Vozes. (Original publicado em 1975)

Ibáñez, T. (1996). Flutuações conceptuales en torno a la Postmodernidad y la Psicología. Caracas, Venezuela: Universidade Central de Venezuela.

Kastrup, V. (1999). A invenção de si e do mundo: Uma introdução do tempo e do coletivo no estudo da cognição. Campinas, SP: Papirus.

Kastrup, V. (2004). A aprendizagem da atenção na cognição inventiva. Psicologia e Sociedade/ABRAPSO, 16(3), 7-16.

Sordi, R. (1999). A comunicação professor-aluno: Uma contribuição ao estudo sobre a construção do conhecimento. Tese de Doutorado não-publicada, Programa de Pós-Graduação em Educação, Universidade Federal do Rio Grande do Sul, Porto Alegre, RS.

Varela, F. (2003). O reencantamento do concreto. Cadernos de subjetividade, PUC-SP, 1(1), 72-86.

Maria Helena De-Nardim é Pedagoga e Psicopedagoga. Mestre em Psicologia Social e Institucional pela Universidade Federal do Rio Grande do Sul (UFRGS). Endereço para correspondência: Universidade Federal do Rio Grande do Sul, Instituto de Filosofia e Ciências Humanas, Departamento de Psicologia, Rua Ramiro Barcelos, 2600, sala 201, Santana, Porto Alegre, RS, 90 035- 003

Regina Orgler Sordi é Doutora em Pós-Graduação em Educação pela Universidade Federal do Rio Grande do Sul (UFRGS) e Professora Adjunta II da UFRGS. 
Endereço para correspondência: Universidade Federal do Rio Grande do Sul, Instituto de Filosofia e Ciências Humanas, Departamento de Psicologia, Rua Ramiro Barcelos, 2600, sala 201, Santana, Porto Alegre, RS,

90 035- 003

osordi@vortex.ufrgs.br

Aprendizagem da Atenção e os Modos de Subjetivação

Pedagógica e Informacional

Maria Helena De-Nardin e Regina Orgler Sordi

Recebido: 25/07/2006

$1^{\text {a }}$ revisão: $20 / 03 / 2007$

Aceite final: 12/09/2007 